\title{
Hydroxyapatite reinforcement of different starch-based polymers affects osteoblast-like cells adhesion/spreading and proliferation
}

\author{
A.P. Marques*, R.L. Reis \\ 3B's Research Group-Biomaterials, Biodegradables, Biomimetics, University of Minho, Campus de Gualtar, 4710-057 Braga, Portugal \\ Department of Polymer Engineering, University of Minho, Campus de Azurém, 4810-058 Guimarães, Portugal
}

Available online 8 March 2005

\begin{abstract}
The aim of this study was to determine which, from a range of the starch-based biomaterials, would be more suitable to be used in orthopaedic applications. This included blends of corn starch and ethylene vinyl alcohol (SEVA-C), corn starch and cellulose acetate (SCA), corn starch and polycaprolactone (SPCL) and its composites with increasing percentages of hydroxyapatite (HA). Osteoblast-like cells (SaOs-2) were cultured in direct contact with the polymers and composites and the effect of the incorporation and of increasing percentages of the ceramic in osteoblast adhesion/proliferation was assessed. In the evaluation of cell adhesion and proliferation rate, two variables were considered; cells adhered to the bottom of the tissue culture polystyrene wells (TCPS) and cells adhered to the surface of the materials, in order to distinguish, respectively: (i) the effect of possible degradation products released from the materials to the culture medium and (ii) the effect of the surface properties on the osteoblast-like cells. In addition, the morphology of cells adherent to the surface of the starch-based polymers was analysed and correlated with their topography and with other chemical properties previously evaluated.

The proliferation rate was found to differ from blend to blend as well as with the time of culture and with the presence of HA depending on the material. SEVA-C and respective composites systematically presented the higher number of cells comparatively to the other two blends. SPCL composites were found to be less suitable for cell proliferation. The amount of cells quantified after 7 days of culture, both on the surface and on the wells showed a delay in the proliferation of the cells cultured with SPCL composites comparatively to other materials and to TCPS. SCA composites, however, did support cell adhesion but also induce a slight level of toxicity, which results in delayed proliferation on the cells adhered to the wells.

Cell morphology on the surface of the materials was also, in almost every case, found to be appropriate. In fact, cells were well adhered and spread on the majority of the surfaces. Thus, starch-based biomaterials can be seen as good substrates for osteoblast-adhesion and proliferation that demonstrates their potential to be used in orthopaedic applications and as bone tissue engineering scaffolds.

(C) 2005 Elsevier B.V. All rights reserved.
\end{abstract}

Keywords: Cell adhesion; Starch-based polymers; Biodegradables; Hydroxyapatite; Tissue engineering; Bone

\section{Introduction}

The evaluation of the biocompatibility of newly developed biomaterials involves numerous steps aiming to assess its safety and suitability for a proposed application. Following the early screening stage where cytotoxicity is evaluated, other concerns, directly correlated with the future application of the materials, arise. Studies start to be

\footnotetext{
* Corresponding author.

E-mail address: apmarques@dep.uminho.pt (A.P. Marques).
}

performed using in vitro culture of cells that will face the implant [1]. For example, the evaluation of biomaterials proposed for orthopaedic applications has been performed using osteoblast-like cells [2-4] and/or primary cultures of osteoblasts [2,5-7]. These are cultured in direct contact with the materials to be tested providing a rapid, sensitive and cost-effective in vitro evaluation, relevant to the function of the device. One of the most important parameters to evaluate is cell adhesion. While for some applications, such as hemocompatibility [8], a reduced cell adhesion is desired, for others, such as orthopaedics [7,9,10], enhanced cell adhesion and proliferation are required. Following adhesion, 
cells can experience activation, which might be evidenced through a variety of processes including spreading, migration, proliferation and biosynthetic activity. Although the precise mechanisms of integrin-related events have not yet been fully elucidated, those processes have been correlated with changes in cell survival, cell proliferation and cellular differentiation [11-13]. Cell spreading involves complex cytoskeleton reorganisation and is an essential function of cell that had become adherent to a surface. Proliferation follows cell spreading and it is central for materials designed to be integrated into host tissues. Osseointegration for example is critical in orthopaedic applications [14].

Cell adhesion and consequent states depend not only on the cell type $[15,16]$ but also on the physical and chemical properties of the material surface $[13,17,18]$. Firstly, these properties control the layer of proteins primarily adsorbed to the material which interact with the integrins, cell-membrane proteins that determine the adhesion and migration behaviour as well as cell morphology $[19,20]$. Although the protein layer adsorbed to the surface of the materials is known to mediate that cell-material interaction, protein adsorption appears neither to be related to a specific site of the substrate nor to induce specific orientation of the ligand. Proteins regulate early events; however, they probably also initiate signalling cascades which regulate long-term events such as protein production [12].

Previous works [18,21-23] have demonstrated that surface topography and surface chemistry play important roles in cell orientation. Therefore, not only cell adhesion, proliferation and differentiation, but also cell morphology, give information about the appropriateness of newly developed biomaterials for a specific application and can be modulated by controlling the surface of the materials.

In the present study, starch-based blends with different synthetic components previously proposed to be used in a wide range of biomedical applications [24-27], were reinforced with increasing percentages of hydroxyapatite (HA) in order to evaluate the effect of the presence and amount of the ceramic in the behaviour of osteoblast-like cells in terms of cell adhesion/morphology and proliferation. Hydroxyapatite is a bioactive material known to promote the differentiation of osteoblastic cells in vitro [28-30]. Moreover, it was suggested [31] that the proteins adsorbed to the surface of HA induced a specific spreading behaviour therefore affecting subsequent proliferation and differentiation.

\section{Materials and methods}

\subsection{Materials}

The materials studied were: (i) a 50/50 (wt.\%) blend of corn starch and ethylene vinyl alcohol (SEVA-C), (ii) SEVA-C reinforced with $10 \%, 20 \%$ and $30 \%$ (wt) of hydroxyapatite (HA, Plasma Biotal, UK), (iii) a 50/50 (wt.\%) blend of corn starch and cellulose acetate (SCA), (iv) SCA reinforced with $10 \%, 20 \%$ and $30 \%$ (wt) of hydroxyapatite, (v) a 30/70 (wt.\%) blend of corn starch and polycaprolactone (SPCL) and (vi) SPCL reinforced with $10 \%, 20 \%$ and $30 \%$ (wt) of hydroxyapatite. In the composites, the average size of $90 \%$ of the HA particles was found to be below $6.5 \mu \mathrm{m}$ (laser granulometry analysis).

All the materials were processed into circular samples $(\varnothing$ $1 \mathrm{~cm}$ ) by injection moulding and sterilised by ethylene oxide under the conditions previously described [24].

\subsection{Cell culture}

A human osteosarcoma cell line SaOs-2, an immortalized cell line with an osteoblastic phenotype, was obtained from European Collection of Cell Cultures (ECACC, UK). The cells were cultured in DMEM (Gibco BRL, Life Technologies, USA) supplemented with $10 \%$ of heat-inactivated fetal bovine serum (FBS; Biochrom AG, Germany), 100000 $\mathrm{U} / \mathrm{ml}$ penicillin-G, $100 \mu \mathrm{g} / \mathrm{ml}$ streptomycin and $25 \mu \mathrm{g} / \mathrm{ml}$ amphotericin B (Sigma Chemical, USA) and $20 \mathrm{mM}$ Hepes (Sigma Chemical, USA) in a humidified atmosphere with $5 \% \mathrm{CO}_{2}$ and at $37{ }^{\circ} \mathrm{C}$.

Cells were trypsinised $(0.25 \%$ trypsin/EDTA solution, Sigma Chemical, USA) from a culture flask and $1.5 \mathrm{ml}$ of cell suspension, in fresh culture medium $\left(3.3 \times 10^{-4}\right.$ cells/ $\mathrm{ml}$ ) was seeded onto the materials. Three samples per material per time of growth were studied and tissue culture polystyrene (TCPS) wells were used as control. The 24-well plates were incubated for 1,3 and 7 days. Culture medium was not changed until the end of the experiment.

\subsection{Microscopy analysis}

After each time of culture, the cells were washed with a $0.1 \mathrm{M}$ phosphate buffered saline solution (PBS, Sigma Chemical, USA), fixed with $2.5 \%$ glutaraldehyde (BDH, UK) solution in PBS for $30 \mathrm{~min}$ at $4{ }^{\circ} \mathrm{C}$, washed and kept in PBS at $4{ }^{\circ} \mathrm{C}$ until being stained or prepared for scanning electron microscopy (SEM) observation.

The surface of the materials was therefore stained with a $0.4 \%$ methylene blue solution in water for $1 \mathrm{~min}$ and examined in a stereomicroscope Zeiss KL 1500 (Zeiss, Germany). For SEM, samples were dehydrated in graded ethanol solutions $(70 \%, 90 \%$ and $100 \%)$ twice, 15 min each and let to dry overnight. Samples were gold sputter coated in a Sputter Jeol JFC 1100 and observed on a Leica Cambridge S360 (Leica Cambridge, UK).

\subsection{Total protein quantification}

In the end of the incubation time, the culture medium was removed and cells were washed with 0.1 M PBS. Materials were transferred to new 24-well plates and $100 \mu$ and 500 
$\mu l$ of $0.1 \mathrm{M}$ PBS were add to each well, respectively, of the initial and new culture plates. From this point on, the BCA Protein Assay kit (Pierce Chemical, USA) was used. This system utilises bicinchoninic acid (BCA) as the detection reagent for $\mathrm{Cu}^{+1}$, which is formed when $\mathrm{Cu}^{+2}$ is reduced by protein in an alkaline environment. The purple coloured reaction product is formed by the chelation of two molecules of BCA with one cuprous ion $\left(\mathrm{Cu}^{+1}\right)$. This water-soluble complex exhibits a strong absorbance at 562 $\mathrm{nm}$ that is linear with increasing protein concentration. At the end of the assay, $100 \mu \mathrm{l}$ of each sample from TCPS wells and from materials were transferred to 96-well plates where a standard curve was prepared and the absorbance read in a multi-well plate reader (SpectraMax 340 PC).

\subsection{Statistical analysis}

The total protein was quantified in four separate experiments, each one carried out with four replicates for each material.
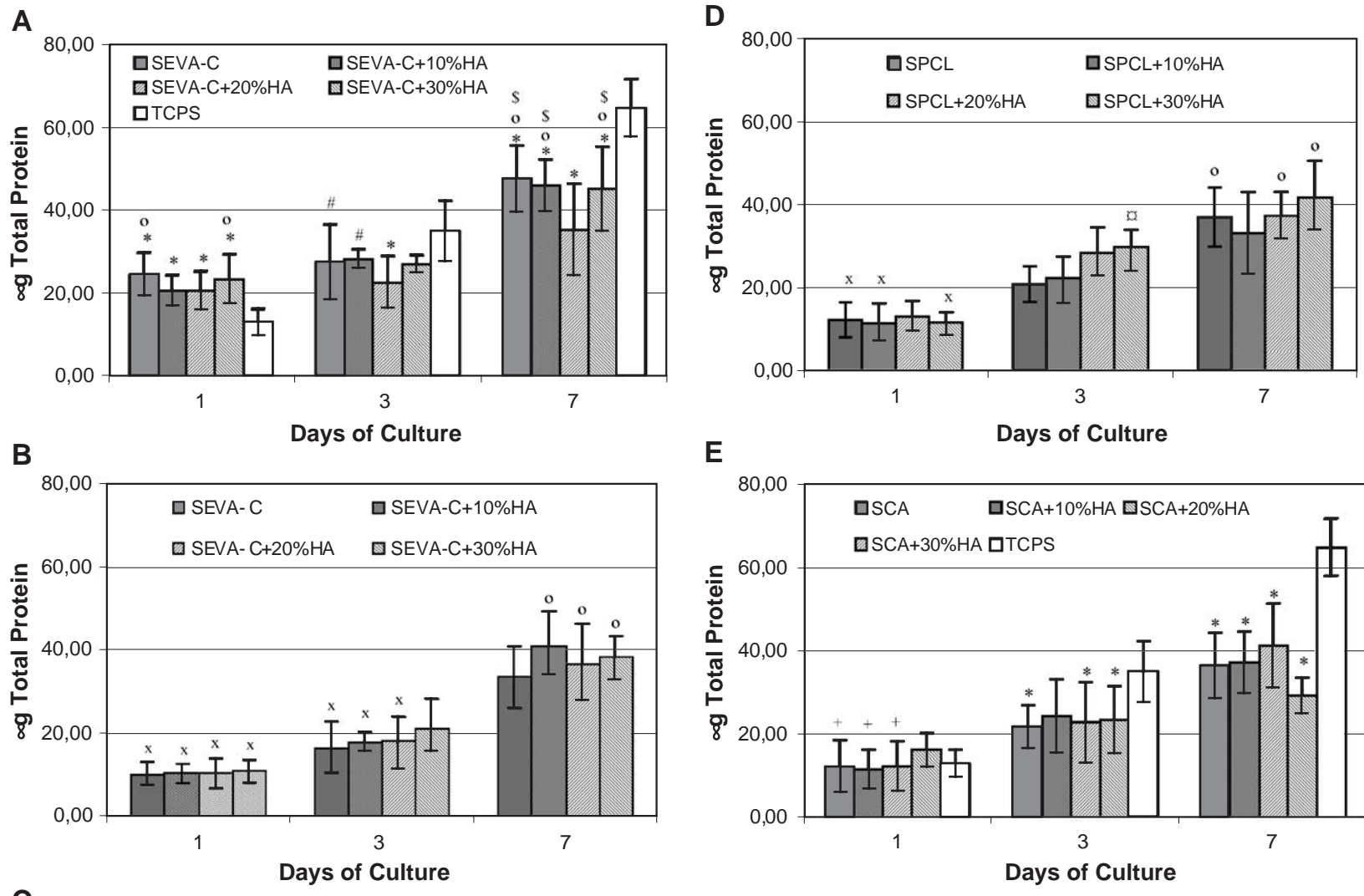

E
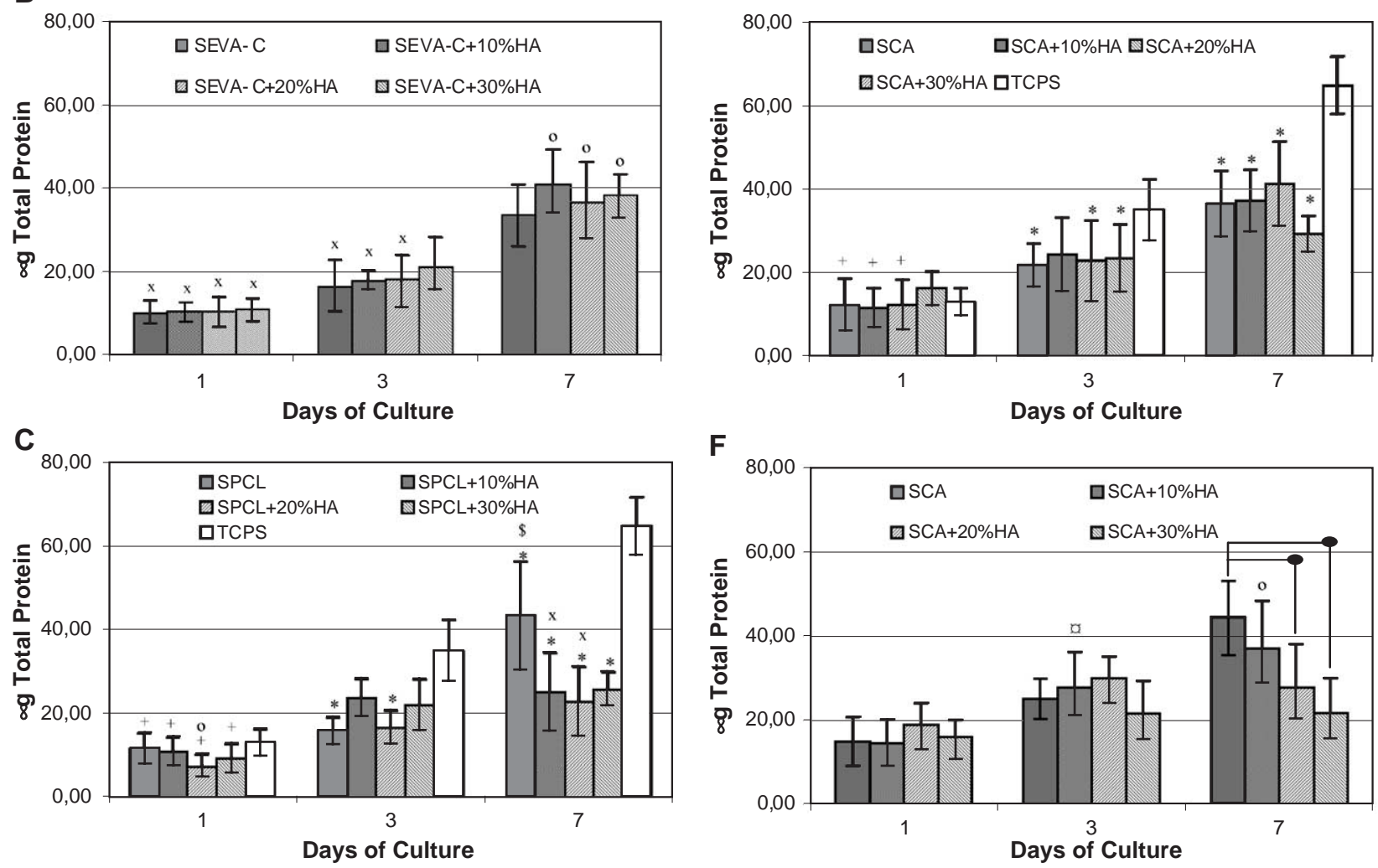

Fig. 1. Amount of total protein quantified in osteoblast-like cells (SaOs-2) cultured in direct contact with SEVA-C and its composites (A, B), SPCL and composites (C, D) and SCA and its composites (E, F) for 1, 3 and 7 days. Total protein was quantified on the materials (A, C, E) and wells (B, D, F). Data represent mean \pm standard deviation, $n \geq 3$. *Significant difference when comparing with TCPS (Control). ${ }^{+}$Significant difference when comparing with SEVA$\mathrm{C}$ and SEVA-C composites. o Significant difference when comparing with SEVA-C. "Significant difference when comparing with SPCL. ${ }^{\$}$ Significant difference when comparing with SPCL composites. ${ }^{\times}$Significant difference when comparing with SCA $+20 \%$ HA. ${ }^{\circ}$ Significant difference when comparing with $\mathrm{SCA}+30 \%$ HA. Significant difference between the connected bars. 



Fig. 2. Scanning electron micrograph showing the surface topography of (A) SEVA-C, (B) SEVA-C+10\% HA, (C) SEVA-C $+20 \%$ HA and (D) SEVA$\mathrm{C}+30 \% \mathrm{HA}$; original magnification $\times 350$. Small squares on the upper corner represent an area of the micrograph at higher magnification $(\times 1000)$. Bar $=100 \mu \mathrm{m}$.

All data was averaged and standard deviation is reported as a measure of sample deviation. The data for the neat extracts was statistically compared by a oneway ANOVA analysis using a Tukey test [32]. If probability values were less than $0.05(p<0.05)$, differences observed for the two materials were considered statistically significant.
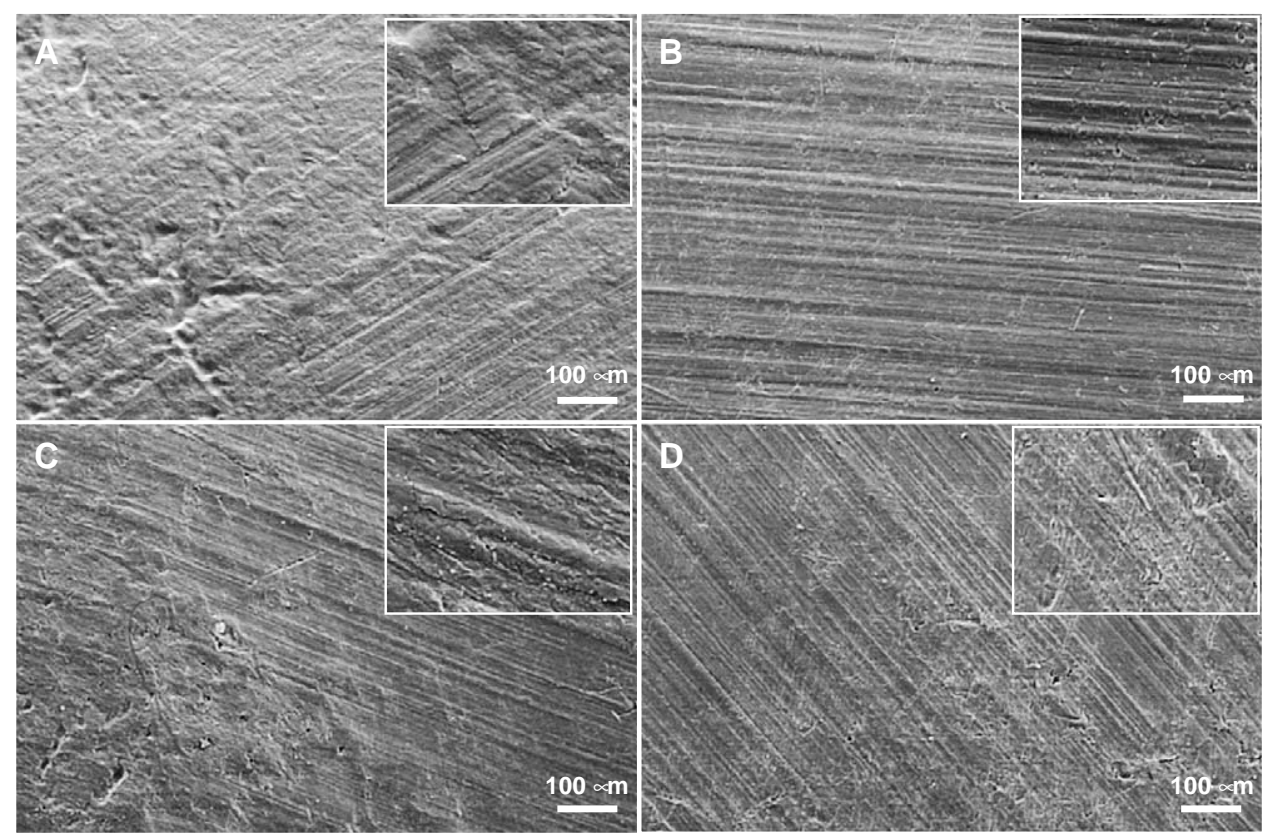

Fig. 3. Scanning electron micrograph showing the surface topography of (A) SPCL, (B) SPCL $+10 \%$ HA, (C) SPCL $+20 \%$ HA and (D) SPCL $+30 \%$ HA. Original magnification $\times 350$. Small squares on the upper corner represent an area of the micrograph at higher magnification $(\times 1000)$. Bar $=100 \mu \mathrm{m}$. 
amount and also to define the initial amount of seeded cells.

The results obtained in the total protein quantification assay were presented as the amount of protein measured from cells adhered to the materials (Fig. 1A, C and E) and from cells adhered to the bottom of the TCPS wells used (Fig. 1B, D and F). The aim was to distinguish the effects of the surface of the polymers studied and of possible toxic degradation products that would affect not only cells on the surface but also the cells adhered to the well. In the majority of the cases, the obtained results were quite good and not typical for other types of biodegradable polymers.

\subsubsection{SEVA-C and composites}

It was observed that osteoblast-like cells have a preference for the polymer and composites with a matrix of starch and ethylene vinyl alcohol (Fig. 1A). After one day of culture, the amount of cells adhered to those materials was higher than the number of cells present in the control TCPS. In fact, this difference was found to be statistically significant. However, after 3 days, the proliferation rate of cells in the control material allowed to reach numbers comparable to the ones observed for cells adhered to SEVA$\mathrm{C}$ and composites. An exception was observed for SEVA$\mathrm{C}+20 \% \mathrm{HA}$, which seemed to delay cell proliferation in such an extent that the amount of total protein after 3 days on that materials was statistically lower than on the TCPS. After 7 days of culture and as expected, the number of cells on the surface of SEVA-C and composites was found to be statistically lower than on the control. From day 3 to day 7 , however, cells on those starch-based biomaterials proliferate at a considerable rate, and although SEVA-C $+20 \%$ of HA seemed to be the less appropriated for cell growth, it was not found to induce a statistically different result from SEVA-C or the other composites with $10 \%$ and $30 \%$ of HA. Therefore, the reinforcement with HA did not seem to have a significant direct effect in the adhesion/proliferation of osteoblast-like cells on the surface of starch-ethylene vinyl alcohol blend, for the studied culture periods.

Considering the effect of the presence of SEVA-C and its composites in the metabolism of cells adherent to the bottom of the wells, there were no statistically significant differences between these materials for any of the times of culture (Fig. 1B). The amount of total protein detected on the wells was lower than the one measured for cells on the surface of those materials except for SEVA-C $+10 \% \mathrm{HA}$ and SEVA-C $+20 \%$ HA, which was comparable. This might be explained by a stronger effect of the surface properties of these materials in contrast with the effect of possible degradation products. For 1 and 3 days, the number of adhered cells in the wells in the presence of SEVA-C and composites was found to be statistically lower when comparing to the results obtained for $\mathrm{SCA}+20 \% \mathrm{HA}$. Therefore, higher adhesion to the bottom of the wells was observed for other starch-based materials, comparatively to SEVA-C and composites; at the same time, a higher number of cells was observed on the surface of SEVA-C and its composites. In addition, after 7 days, the number of cells in the wells in the presence of SEVA-C composites is higher than in the presence of SCA composites and statistically different comparatively with $\mathrm{SCA}+30 \% \mathrm{HA}$. We might speculate that at early culture times, osteoblast-like cells consider the surface of SEVA-C and its composites "friendly" enough to adhere/proliferate instead of migrating

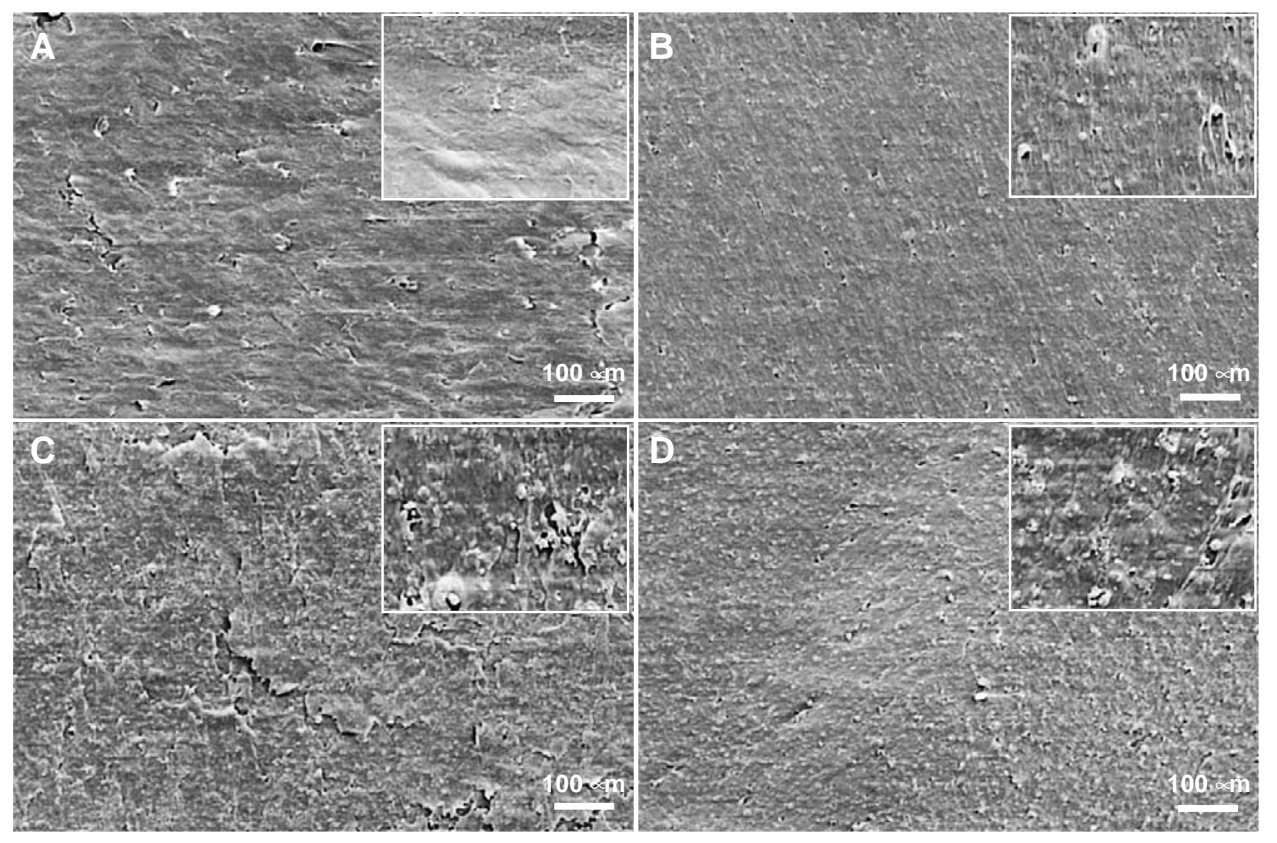

Fig. 4. Scanning electron micrograph showing the surface topography of (A) SCA, (B) SCA $+10 \% \mathrm{HA}$, (C) SCA $+20 \%$ HA and (D) SCA $+30 \% \mathrm{HA}$. Original magnification $\times 350$. Small squares on the upper corner represent an area of the micrograph at higher magnification $(\times 1000)$. Bar $=100 \mu \mathrm{m}$. 
to the TCPS and a possible equilibrium starts to be established for longer culture times.

\subsubsection{SPCL and composites}

The results obtained for SPCL and its composites were considerably different to what was observed for the blend of starch-ethylene vinyl alcohol. The number of cells quantified on the surface of SPCL and respective composites was statistically lower comparatively to SEVA-C and its composites at day 1. Interestingly, for this same time of culture, the amount of total protein obtained from cells adhered to SPCL and its composites was comparable to the value obtained for control (TCPS) (Fig. 1C). At day 3, however, the proliferation rate in the TCPS had prevailed inclusively being statistically higher than on the surface of SPCL and SPCL $+20 \%$ HA. Furthermore, the number of cells on the surface of SPCL was also found to be statistically lower comparatively to SEVA-C and SEVA-

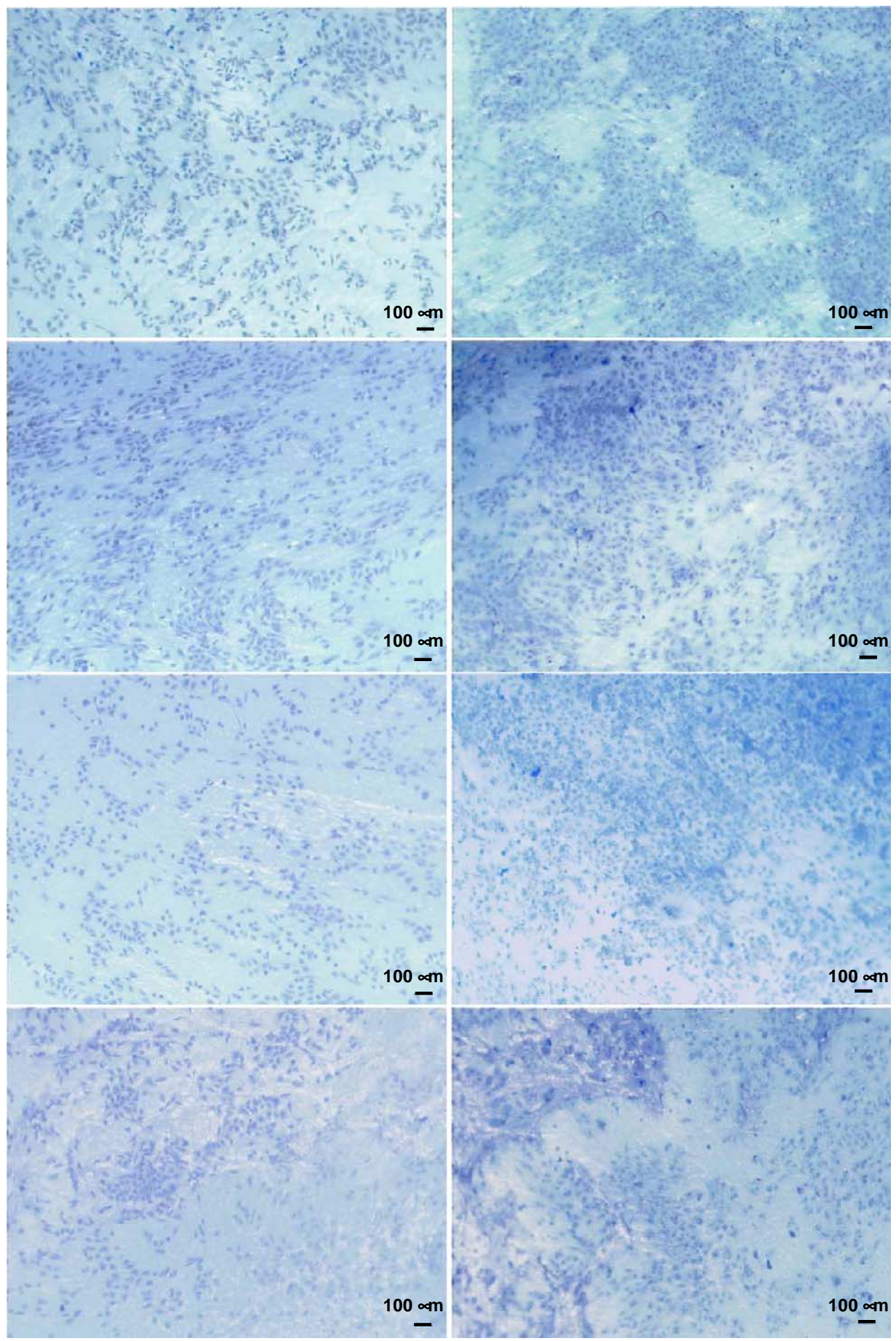

Fig. 5. Optical micrograph of osteoblast-like cells (SaOs-2) stained with methylene blue cultured on SEVA-C and its composites for 3 and 7 days. Bar=100 $\mu$ m. 
$\mathrm{C}+10 \% \mathrm{HA}$ for the same time of culture. As observed for the materials of starch-ethylene vinyl alcohol, after 7 days of culture, the number of cells quantified for the TCPS was statistically higher than for SPCL and composites.

Contrarily to what was observed for the starch-ethylene vinyl alcohol blend, the reinforcement of SPCL had a quite strong effect on osteoblast-like cell behaviour in particular for longer times of culture. At day 7, SPCL composites were no longer suitable for cell proliferation presenting a number of adherent cells statistically lower than the unreinforced polymer (SPCL) and SEVA-C and its composites with 10\% and $30 \% \mathrm{HA}$.

The measurement performed in the wells where osteoblast-like cells were cultured with the starch-polycaprolactone blend, showed completely distinct results. Comparing the values obtained for the different materials of the two blends at each time of culture, only in the presence of SEVA-C the cell number was found statistically lower than in the presence of SPCL $+30 \%$ HA (Fig. 1D). At day 1, however, the number of cells in the wells in the presence of SPCL, SPCL $+10 \% \mathrm{HA}$ and SPCL $+30 \% \mathrm{HA}$ was found to be statistically lower comparatively to SCA $+20 \%$ HA. After 7 days, this difference was again noted between SPCL and $\mathrm{SCA}+30 \% \mathrm{HA}$. Contrarily, at the same time of culture in the wells in contact with SPCL+20\% HA and SPCL $+30 \% \mathrm{HA}$, the number of cells was statistically higher than in contact with $\mathrm{SCA}+10 \% \mathrm{HA}$.

Apparently, the effect of the degradation products of the starch-ethylene vinyl alcohol and starch-polycaprolactone blends was not significant and no correlation could be made. Nonetheless, and contrarily to what was found for SEVA-C and respective composites, the amount of total protein in the wells was higher than on the surface of SPCL and respective composites for all the times of culture. Thus, the surface of these starch-based biomaterials does not seem to be preferred over the TCPS wells. Taking into account that after 7 days of culture, SPCL composites did not support higher number of cells than after 3 days, it would be expected that the number of cells on the wells, where those materials were present, would be higher. However, the obtained values were comparable to those measured in the presence of the unreinforced polymer (SPCL) which demonstrates that the properties of the surface of the SPCL composites are in fact ruling and delaying osteoblast-like proliferation on its surfaces.

\subsubsection{SCA and composites}

The number of cells quantified on the surface of SCA and respective composites, as observed for the blend of starch-polycaprolactone, was statistically lower comparatively with SEVA-C and its composites at day 1. At this time of culture, no difference was observed comparing to the control TCPS although after 3 days the amount of protein in the starch-cellulose acetate materials, except for SCA $+10 \%$ HA, was already significantly lower. At the end of the assay, SCA and its composites presented a significantly lower adhesion/proliferation on their surfaces comparatively to TCPS. In the third day of culture, no significant differences were observed between the amount of cells quantified on the surface of SCA and its composites and on the surface of the other materials. Differences occurred at day 7 between SEVA-C, respective composites and $\mathrm{SCA}+30 \% \mathrm{HA}$ and between SPCL $+10 \%$, SPCL $+20 \%$ HA and SCA $+20 \% \mathrm{HA}$, which were found to be the SCA composites respectively with lower and higher number of cells at this time point.

As for the starch-ethylene vinyl alcohol blend, the reinforcement of SCA with HA did not have a significant effect on osteoblast-like cell adhesion although SCA $+30 \%$ HA presented the lowest amount of total protein.

Contrarily to the other two starch-based blends, the degradation products of SCA composites had an effect on the adhesion and proliferation of osteoblasts-like cells on the bottom of the wells. After 7 days of culture, for increasing percentages of ceramic, the number of total protein decreased while the number of cells increased in the wells but not on the surface of the unreinforced materials. Thus, in the case of SCA and composites, the reinforcement of the polymer could be favourable for cell adhesion if the effect of the degradation rate and consequently of the degradation products did not mask the effect of the surface properties. Comparatively to the polymer without HA, we would say that the surface properties of the composites are more favourable for osteoblast-like cells adhesion and proliferation since the amount on their surfaces is comparable even in the presence of proliferation delaying molecules.
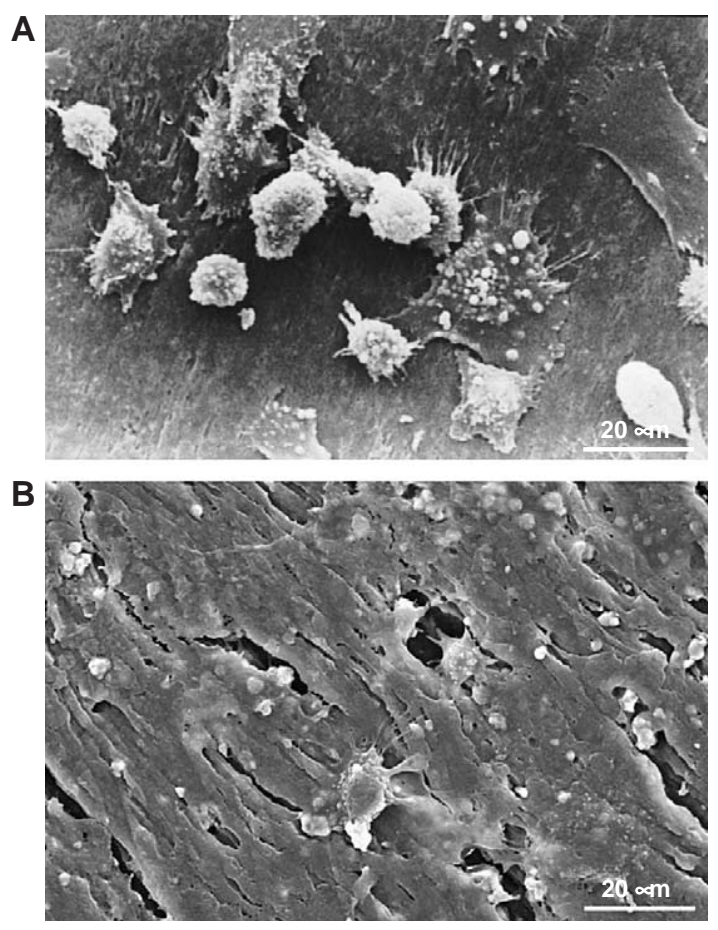

Fig. 6. Scanning electron micrograph of osteoblast-like cells (SaOs-2) on (A) SEVA-C and (B) SEVA-C $+20 \%$ HA after 3 days of culture. Bar $=20 \mu \mathrm{m}$. 


\subsection{Surface topography}

The morphology of the materials analysed by SEM, showed that SEVA-C possesses a quite irregular surface with some areas of intense irregularities (Fig. 2A). At higher magnification, it was possible to note that SEVA-C surface is highly asymmetrical with some areas rougher than others although this blend has been reported [33] to be an interpenetrating network (IPN). After the incorporation of $10 \%$ of HA, the surface of the material has become uniform although the presence of HA particles seemed to introduce a rough character to this composite (Fig. 2B). The SEVA-C composite with $20 \%$ of HA showed again a rather inhomogeneous surface (Fig. 2C) that even seemed to have, in comparison with the composite with $10 \% \mathrm{HA}$, some smoother areas. The increasing in the percentage of HA incorporated from $20 \%$ to $30 \%$ did not show significant changes in surface topography (Fig. 2D). In fact, HA

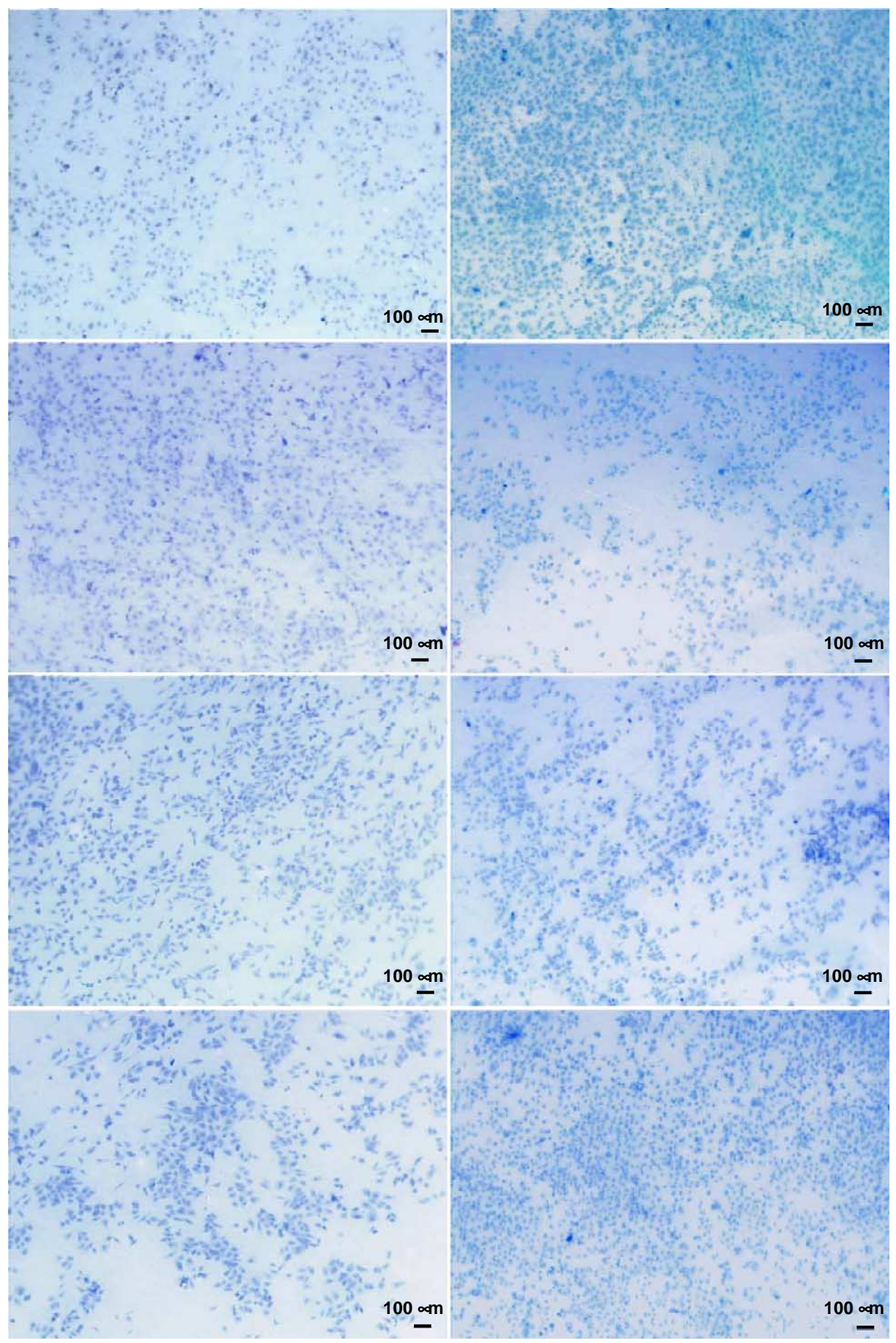

Fig. 7. Optical micrograph of osteoblast-like cells (SaOs-2) stained with methylene blue cultured on SPCL and its composites for 3 and 7 days. Bar=100 $\mu$ m. 
particles are dispersed all over the surface and we might speculate that the difference between those two composites would be the amount of HA granules on the surface. Thus, the topography/morphology of the surfaces of the polymers and composites of starch with ethylene vinyl alcohol has changed with the incorporation of HA.

Contrarily to the surfaces of SEVA-C and composites, SPCL and SPCL reinforced with HA presented smoother surfaces (Fig. 3). In addition, the reinforcement of the SPCL polymer with HA may have introduced some roughness on the surfaces of the composites, in particular to SPCL $+30 \%$ HA. These differences are not notorious and HA particles were not clearly observed on the surface of SPCL composites.

The morphology of the surface of SCA was not comparable to any of the other starch-based biomaterials (Fig. 4A). This material was quite rough and the reinforcement of SCA with HA has resulted, in this blend in a notorious way, in rougher surfaces for increasing percentages of ceramic. Since SCA is the more immiscible blend, the HA particles were visibly present in the surface and in great amounts for $\mathrm{SCA}+30 \% \mathrm{HA}$ (Fig. 4D).

\subsection{Cell adhesion/morphology}

The adherence of osteoblast-like cells on the surface of starch-based materials was assessed after methylene blue staining. Cells were adhered all over the surface of SEVA-C and composites after 1 and 3 days of culture (Fig. 5A, C, E and $G$ ) presenting the typical polygonal shape of osteoblastic cells, therefore showing the suitability of the substrates for adherence. The morphology of the cells was analysed in detail by SEM which allowed to see that cells have different morphologies when adhered to SEVA-C comparatively to its composites (Fig. 6). After 3 days of culture, there were some completely spread cells with extended lamelipodia to the material but also some cells still starting to flatten (Fig. 6A). These cells presented filopodia towards the material with some of them already showing lamelipodia. In the case of SEVA-C composites, cells were much more spread, highly connected with the surface (Fig. 6B). Only few cells were showing filopodia and in the direction of HA particles. However, no significant differences were observed for different percentages of reinforcement.

After 7 days of culture, as it was demonstrated by total protein quantification, cells proliferated well on the surface of those materials. In fact some areas of the samples were covered with a monolayer of cells (Fig. 5B, D, F and H), again indicating that SEVA-C and respective composites possess appropriated properties for osteoblast-like cells adhesion. The SEM observation of these surfaces after 7 days of culture proved that cells were completely spread on the surface forming a monolayer. On SEVA-C, it was however still possible to distinguish the cell contours, while in the case of composites, cells were interconnected being impossible to delineate each one of them.
The adhesion of osteoblast-like cells on SPCL and respective composites was, at early times of culture and in terms of cell distribution and morphology, similar to what was observed for SEVA-C and SEVA-C composites. Cells seemed to show the typical osteoblastic morphology although this was more obvious for SPCL composites with $20 \%$ and $30 \%$ of HA (Fig. 7A, C, E and G). SEM evaluation of cell morphology showed that cells on the surface of

A

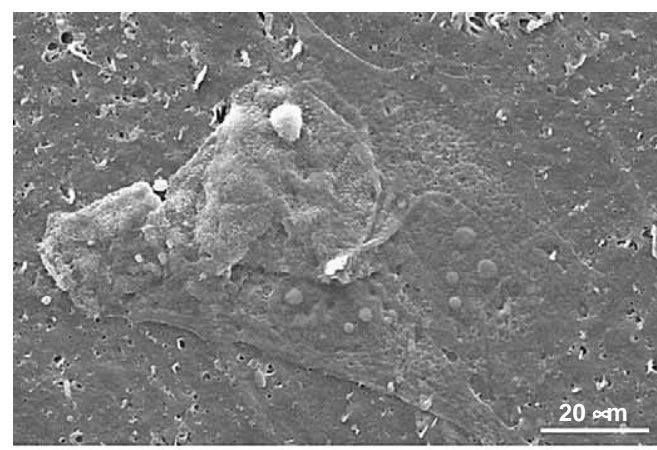

B

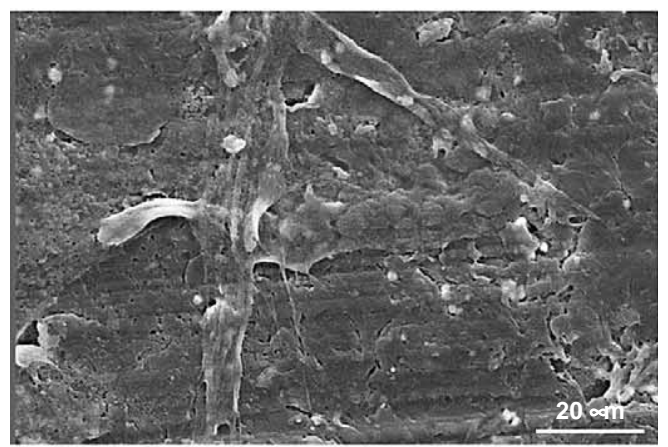

C

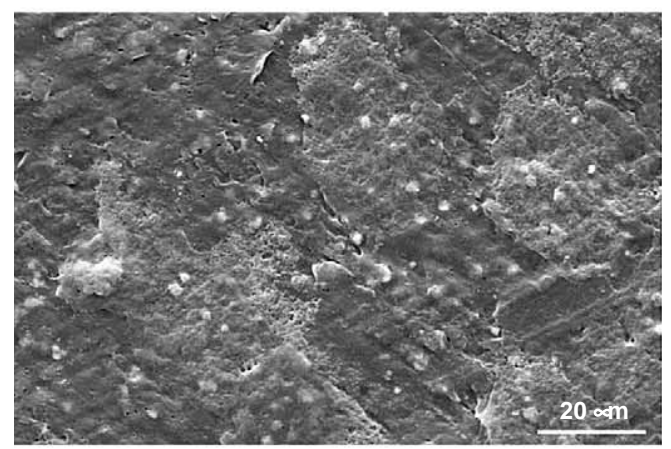

D

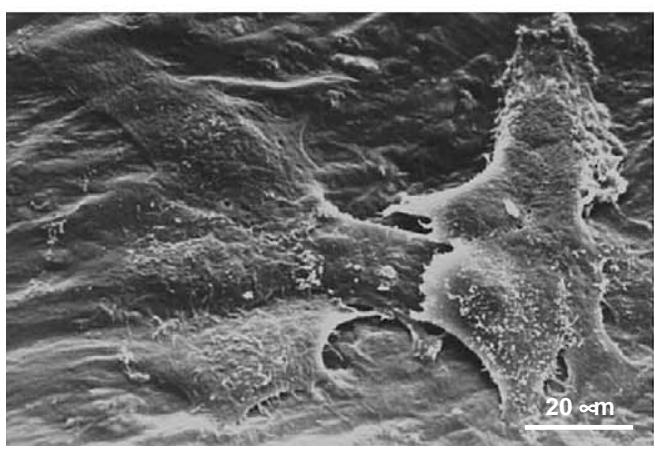

Fig. 8. Scanning electron micrograph of osteoblast-like cells (SaOs-2) on (A) SPCL, (B) SPCL $+10 \% \mathrm{HA}$, (C) SPCL $+20 \% \mathrm{HA}$ and (D) SPCL $+30 \%$ $\mathrm{HA}$ after 3 days of culture. Bar $=20 \mu \mathrm{m}$. 
SPCL and SPCL $+10 \%$ HA were spread on the surface and merging other cells in the periphery (Fig. 8A, B). These observations were not exactly the same for cells adhered to the surface of SPCL $+20 \%$ HA and SPCL $+30 \%$ HA. Cells were also spread, in a higher extent on SPCL $+20 \%$ HA, but it was possible to distinguish independent cells. Thus increasing percentages of HA did not seem to favour cell spreading and proliferation on the surface of SPCL materials.
After 7 days of culture, the results obtained for total protein quantification were proved once again. SPCL composites were found not to be the ideal substrate for cell proliferation (Fig. 7D, F and H). Cells were starting to form agglomerates in certain areas of the surface of the composites contrarily to what was observed on the surface of the unreinforced SPCL, which showed cells all over the surface (Fig. 7B). In fact, the SEM observation showed that the cells on the surface of SPCL materials were starting to

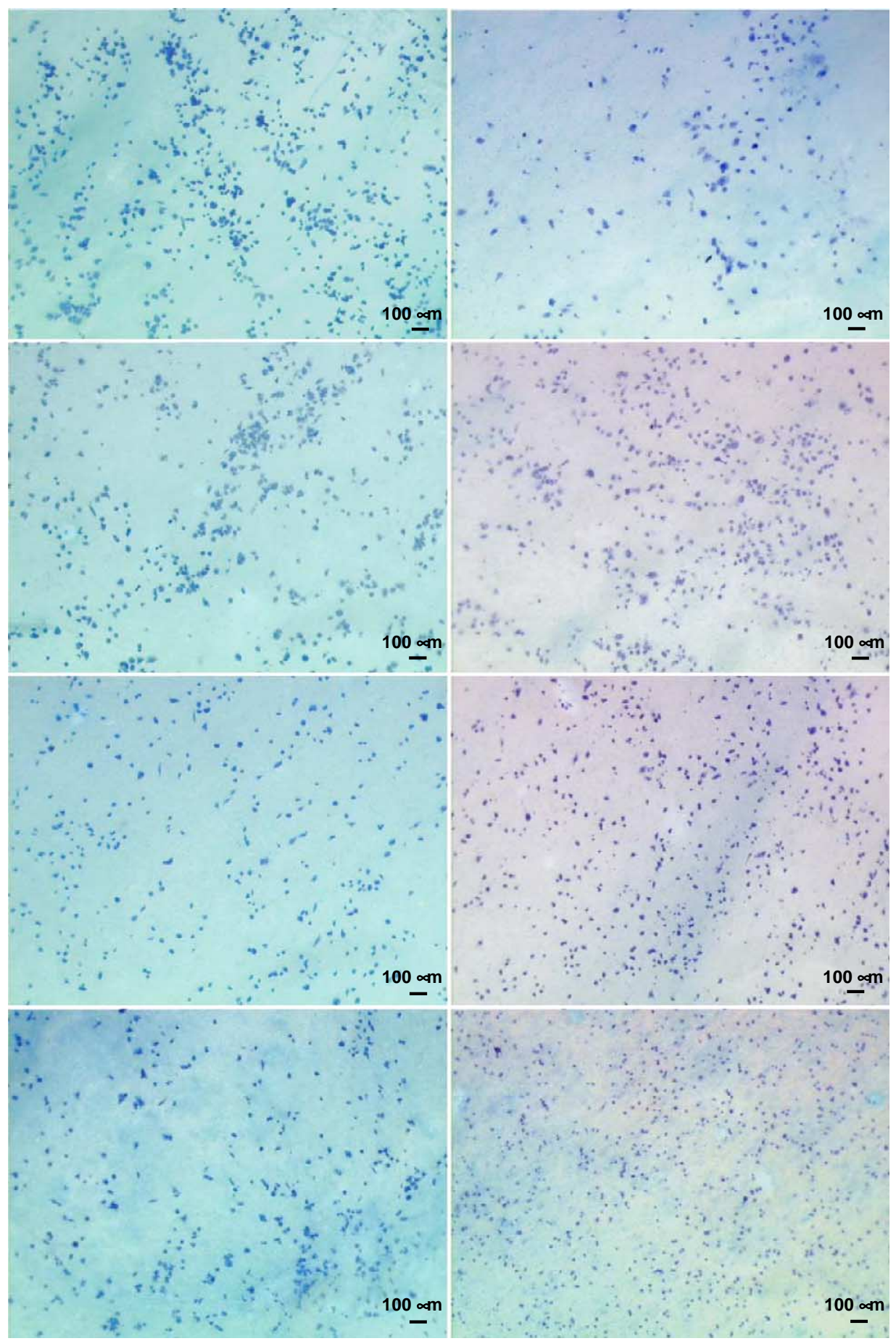

Fig. 9. Optical micrograph of osteoblast-like cells (SaOs-2) stained with methylene blue cultured on SCA and its composites for 3 and 7 days. Bar=100 $\mu$ m. 
retract after 7 days of culture. The majority of the cells were not spread starting to extend filopodia, which seems to be an attempt to remain attached to the surfaces. Thus, although the surface properties of SPCL and its composites were suitable for initial cell attachment and adhesion, it was found that for increasing times of culture and consequent changes on the surface characteristics as time goes by may


Fig. 10. Scanning electron micrograph of osteoblast-like cells (SaOs-2) on (A) $\mathrm{SCA}$, (B) $\mathrm{SCA}+10 \% \mathrm{HA}$, (C) $\mathrm{SCA}+20 \% \mathrm{HA}$ and (D) $\mathrm{SCA}+30 \% \mathrm{HA}$ after 7 days of culture. Bar $=20 \mu \mathrm{m}$. render those surfaces improper (less adequate) for osteoblast-like proliferation.

Comparatively to the other blends, the starch-cellulose acetate did not support so well osteoblast-like cell attachment and adhesion. For all the times of culture, cells did not present the characteristic morphology of osteoblasts and were preferential adhered to some areas of the surface instead of being all over it (Fig. 9). In addition, the differences between SCA and its composites did not seem to be significant. The detailed observation of cell morphology confirmed that although adhered to the SCA and respective composites using cytoplasm extensions, the majority of the cells were not spread and its nucleus was prominent and easily identifiable (Fig. 10). The amount of spread osteoblasts, comparatively to round cells, on the surface of SCA was still considerable after 7 days (Fig. 10A) which may constitute a good sign in terms of suitability of this material for cell adhesion and proliferation. However, for higher percentages of HA, the amount of spread cells decreases (Fig. 10B, C and D). Thus, contrarily to what should be expected, in the presence of HA, the morphology of osteoblasts on the surface of SCA composites did not seem to be ideal for cell proliferation.

\section{Discussion}

Surface characteristics of the materials, whether their topography $[23,30]$, chemistry $[21,30,34,35]$ or surface energy $[29,36]$, play an essential part in osteoblasts adhesion to biomaterials. Attachment, adhesion and spreading belong to the first phase of cell/material interaction and the quality of this stage influences the capacity of cells to proliferate and differentiate itself on contact with the implant [12].

Cell attachment represents the translation of certain physico-chemical events involving the chemical interaction between cells and materials [12]. This is followed by cell adhesion, which is the result of biological processes such as production of extracellular matrix proteins, cytoskeleton proteins reorganisation among others [12]. Cell adhesion and spreading were shown to be clearly distinguishable biological phenomena because substrates that allow cell adhesion do not necessary promote cell spreading [37]. Furthermore, it was previously suggested [38] that surfaces that show good cell attachment at early time points do not necessarily promote cell proliferation or differentiation.

This study was performed in order to determine which of the starch-based biomaterials would be more suitable for the development of biomedical device for orthopaedic applications and bone tissue engineering scaffolding. The effect of the incorporation and of increasing percentages of a ceramic in osteoblast adhesion/proliferation was also assessed for the three starch-based materials. The experiment was set in order to distinguish the effect of the surface properties on the adhesion/proliferation rate of osteoblast-like cells from possible degradation products released from the materials to 
the culture medium. Furthermore, cell morphology was also analysed and correlated with the topography of the surface of the materials.

Cell growth capacity was shown to be influenced by different chemistries of the materials [21,30,34,35]. For example, hydroxyl groups are known to enhance cell adhesion and growth $[39,40]$. These groups are responsible for higher surface polarity and hydrophilicity of the surface [13]. However, a correlation between these two parameters has not been a consensus. Some authors $[15,41,42]$ defend that cell adhesion is generally better on hydrophilic surface. However, other studies $[11,13,28]$ showed that osteoblast-like cells do not display a consistent trend of behaviour in relation to surface wettability but rather varied as a function of particular functional groups. Studies with osteoblasts $[29,36]$ suggested that cell adhesion was greatly influenced by the polar interaction energy, which emphasises the role of surface energy in this biological process.

Due to their starch component, the materials in study have high number of hydroxyl groups on their surfaces. In addition, SCA is the more hydrophilic material and possesses higher content of oxygen [43]. Thus, it would be expected, based on this properties, that the blend of starch with cellulose acetate would have higher number of cells adhered to its surface. However, SEVA-C with the lowest oxygen content and a less hydrophilic [43] surface than SCA presented higher cell adhesion and a regular proliferation rate. SCA is a non-miscible blend and due to its higher water uptake capability and degradation rate experiences more and more rapidly changes on its surface which definitely determine and influence cell behaviour.

In addition to chemistry, osteoblasts react differently according to surface topography $[23,30]$ and roughness $[4,22,40,44]$. Rougher surfaces were shown to reduce proliferation of osteoblast-like $[4,44]$ and human bone derived cells $[22,45]$. In addition, the initial adhesion of osteoblast-like cells was shown to be greater on polished (smoother) surfaces [4].

A direct relationship exists between roughness and surface energy of the materials and it was demonstrated that the apolar component of surface energy increased significantly with roughness [46]. Furthermore, it was reported [47] that for relatively low surface roughness values, cell responses to the surface chemistry are more important than the physical surface.

In terms of topography, starch-based biomaterials presented different surfaces apparently showing irregularities that might influence cell adhesion. SPCL polymer seems to have the smoother surface [48]. Therefore, the wettability and roughness of SPCL would indicate that this material did not present the best properties for cell adhesion. However, cells adhered to its surface similarly to SEVA-C, which might suggest that roughness plays a more important role than wettability in cell adhesion to SPCL. In addition, the oxygen content of SPCL is similar to SCA [43] and we could suggest that it also has a role in osteoblast-like cells adhesion to SPCL.

After cells contact surfaces, they will alter their cell membrane and its morphology to stabilise the cellmaterial interface [49]. When cell adhesion was followed by progressive flattening of the cells, proliferation occurred [50].

Some studies [11,13,22,51] demonstrated ultrastructural differences in cell spreading and filopodia forming in dependence on a surface even if no differences in the percentage of adherent cells were observed [51]. Filopodia, finger-like protrusions of plasma membrane formed as a consequence of actin assembling in long bundles or lamellipodia if assembled in the form of mesh supporting sheet-like protrusions are morphological details, characteristic of cell adhesion [12].

Morphological aspects, like cell adhesion and proliferation, have also been shown to be influenced by different chemistries of the materials $[11,13,15,30]$. A critical value for the surface energy of the substratum above which cell spreading occurs, was previously established [20]. Likewise, cytoskeleton organisation and cell morphology are regulated by surface wettability $[11,36]$. Cell attachment and spreading are generally greater on certain moderately hydrophilic surfaces relative to hydrophobic ones $[11,36]$.

Surface wettability of starch-based materials definitely influences cell morphology. SEVA-C materials with intermediate hydrophilicity has shown highly spread osteoblastlike cells on its surface while cells on the surface of SCA, the most hydrophilic material, were adhered but not flat or spread. Interestingly enough, the hydrophobic surface of SPCL material supported cell adhesion and spreading for early but not for longer culture times. Osteoblasts are also shown to recognise substrate morphology and to respond by altering their spreading degree [52,53]. Several studies $[4,22]$ have demonstrated that cell spreading and continuous cell layer formation were better on smooth surfaces compared to rough ones. However, Bigerelle et al. [54] suggested that topography below the cell scale favours polygonal morphology of osteoblasts although when the topography was considered above the cell scale, they also appreciate the roughness which may explain cells being spread and flattened on surfaces considered rough [52]. Morphologically, cell layer organisation was also modified by the roughness of the underlying substrates [22]. Our results are, in some extent, in accordance with these observations; the rougher material, SCA, showed the lower osteoblast flattening degree. However, on the smoother surface (SPCL), cells were very spread at short culture times but the surface was not able to support a cell layer.

As the surface characteristics determine how proteins adsorb to the surface $[55,56]$ and more particularly determine the orientation of those adsorbed molecules $[17,57]$, proteins constitute another variable in the cell attachment/adhesion process. Fibronectin (Fn) and vitronectin $(\mathrm{Vn})$ have been shown to be involved in osteoblast 
adhesion in vitro $[19,22,58,59]$ although they preferentially adhere to Fn $[19,59,60]$. However, the surface charge or the material might counteract this response [19]. Fn undergoes greater conformational change when adsorbed onto hydrophobic surfaces than on hydrophilic ones while the conformational changes on adsorption of $\mathrm{Vn}$ is substrate independent [56-58]. In addition, in vitro cell attachment was shown to be primarily mediated by Vn due to its ability to adsorb to the substrate in competition to other serum proteins $[19,58,61]$. Attachment to TCPS in vitro also depends on Vn adsorption [61].

A previous study [33] with starch-based polymers and protein adsorption from serum showed that vitronectin is the protein that adsorbs in higher amount to those materials. Furthermore, SPCL was the material with higher amount of adsorbed Vn in comparison with SEVA-C and SCA [33]. Thus, it is likely that this protein plays a major role in the initial cell attachment to SPCL. The surface properties determine that initially $\mathrm{Vn}$, when adsorbed onto this polymer, will adopt a conformation that is ideal for cell attachment which becomes less favourable or desorbs from the surface with increasing periods of culture.

Bone has been shown to mechanically react to an HA surface in vivo [14]. However, the in vitro attachment and growth of osteoblast cells on HA ceramics or other biodegradable polymer reinforced with it has been reported $[3,9]$ to be significantly low compared to a range of orthopaedic biomaterials.

When osteoblasts were cultured with HA particles, the cell population was significantly decreased [62]. Fine particles of HA, normally a non-toxic material were shown to cause cell damage in vitro [63], which depend on the direct contact between cells and particles resulting in cell membrane damage. On the other hand, the test material may have a low level of toxicity, which although not sufficient to kill cells, may inhibit normal cell function. The intracellular dissolution of calcium-containing crystals was also proved to greatly influence cell behaviour $[64,65]$. Osteoblasts have been implicated in calcium-phosphate degradation $[2,66,67]$ which leads to a significant inhibition growth. The explanation suggests that the presence of HA particles and its intracellular solubilisation could adversely affect homeostatic mechanisms and mechanical regulators of DNA synthesis can be modified without any expression of cytotoxic effect [2].

In another study [68], the degradation of hydroxyapatite powders was also associated with poor cellular response but in this case, the effect was attributed to an increase in the amount of impurity ions released. High phosphate ion concentration released from ceramics has also been suggested as being inhibitory to cell activity [5].

Previous short- and long-term studies [69-71] with SEVA-C-based HA composites and different types of cell lines have shown promising results which were confirmed in this study. The release of HA particles during the experiment may only constitute an explanation for SCA composites since it was only with these materials that the proliferation rate on TCPS was kept or reduced and only for longer times of culture. In fact, SCA is the material with higher water uptake capability and a higher access to the inner HA particles within the composite and a higher susceptibility to hydrolysis at the interface polymer-HA comparatively to the bulk of the material. The easier access to those interfaces facilitates the degradation of the material with the release of not only HA particles but also low molecular weight chains responsible for a $\mathrm{pH}$ drop. Thus, for the periods of time tested, the amount of released HA particles may induce some inhibitory activity on the osteoblasts.

Furthermore, the surface properties of SPCL composites were shown to be inappropriate for cell proliferation. In this particular case, HA particles itself do not seem to be responsible for this behaviour. In turn, the incorporation of the ceramic seemed to have affected the surface properties in such a way that between 3 and 7 days osteoblast decreased its proliferation rate.

The composition and topography of HA composites influenced the morphology of cells, showing that cell spreading was more pronounced on exposed HA regions of the composite [72]. In addition, human osteoblasts showed propensity for spreading at early time points on surfaces containing exposed HA particles [72].

A slow rate of osteoblast-like proliferation on HA as well as weak affinity of fibronectin to that ceramic have been previously reported [73] and associated with the physicochemical characteristic of the material. In another study [31], vitronectin and fibronectin were not only found to adsorb to HA but also to participate in the osteoblast spreading on that material.

In this work, one could confirm that, in comparison to unreinforced polymer, starch-based composites induced more pronounced cell spreading. The miscibility character of each one of the starch-based blends also determines the exposure of the HA particles within the samples. Thus, SCA as the more immiscible blend and the more hydrophilic material, presented higher amount of HA on its surface and higher access to the HA particles in the bulk of the composite, was expected to show higher spreading of osteoblasts. However, the spreading of osteoblasts on SCA composites was not as notorious as on SEVA-C and SPCL composites.

\section{Conclusions}

The results reported in this study indicate that the physico-chemical properties of starch-based biomaterials influenced adhesion, proliferation and morphology/spreading of osteoblast-like cells. Depending on the starch blend, thus on its synthetic component and the properties that it confers to the surface, cells proliferate at different rates. Furthermore, the incorporation of hydroxyapatite also had 
different effects according to the polymer matrix used. In the case of SCA, it seemed to change its degradation behaviour and consequently the degradation products released to the culture medium, which delayed cell proliferation. In the case of SPCL, the incorporation of HA induced changes in the surface properties that induced cell detaching for longer culture times. Different percentages of HA did not seem to change significantly osteoblast-like cell behaviour.

Overall results indicate that starch-based biomaterials present characteristics of cell adhesion/spreading and proliferation that are not disappointing considering their degradable nature. In fact, as shown in other works, these polymers and composites may find several applications in orthopaedics and tissue engineering scaffolding.

\section{Acknowledgements}

The authors gratefully acknowledge the Portuguese Foundation for Science and Technology (FCT) and the Portuguese Programme PRAXIS XXI for awarding a PhD Grant to A. P. Marques (SFRH/BD1276/2000). This work was also partially supported by FCT Foundation for Science and Technology, through funds from the POCTI and/or FEDER programmes.

\section{References}

[1] C.J. Kirkpatrick, F. Bittinger, M. Wagner, H. Kohler, T.G. van Kooten, C.L. Klein, M. Otto, Proc. Inst. Mech. Eng., H J. Eng. Med. 212 (1998) 75.

[2] B. Alliot-Licht, M. Gregoire, I. Orly, J. Menanteau, Biomaterials 12 (1991) 752 .

[3] H.M. Elgendy, M.E. Norman, A.R. Keaton, C.T. Laurencin, Biomaterials 14 (1993) 263.

[4] L. Bacakova, V. Stary, O. Kofronova, V. Lisa, J. Biomed. Mater. Res. 54 (2001) 567.

[5] C. Knabe, R. Gildenhaar, G. Berger, W. Ostapowicz, R. Fitzner, R.J. Radlanski, U. Gross, Biomaterials 18 (1997) 1339.

[6] H. Zreiqat, C.R. Howlett, A. Zannettino, P. Evans, G. Schulze-Tanzil, C. Knabe, M. Shakibaei, J. Biomed. Mater. Res. 62 (2002) 175.

[7] M.J. Dalby, L. Di Silvio, N. Gurav, B. Annaz, M.V. Kayser, W. Bonfield, Tissue Eng. 8 (2002) 453.

[8] M.C. Belanger, Y. Marois, J. Biomed. Mater. Res. 58 (2001) 467.

[9] D.A. Puleo, L.A. Holleran, R.H. Doremus, R. Bizios, J. Biomed. Mater. Res. 25 (1991) 711.

[10] L. Calandrelli, B. Immirzi, M. Malinconico, G. Orsello, M.G. Volpe, F. Della Ragione, V. Zappia, A. Oliva, J. Biomed. Mater. Res. 59 (2002) 611.

[11] J.H. Lee, J.W. Lee, G. Khang, H.B. Lee, Biomaterials 18 (1997) 351.

[12] K. Anselme, Biomaterials 21 (2000) 667.

[13] P. Filippini, G. Rainaldi, A. Ferrante, B. Mecheri, G. Gabrielli, M. Bombace, P.L. Indovina, M.T. Santini, J. Biomed. Mater. Res. 55 (2001) 338 .

[14] S. Santavirta, D. Nordstrom, P. Ylinen, Y.T. Konttinen, T. Silvennoinen, P. Rokkanen, Arch. Orthop. Trauma Surg. 110 (1991) 288.

[15] J.H. Lee, S.J. Lee, G. Khang, H.B. Lee, J. Biomater. Sci., Polym. Ed. 10 (1999) 283.

[16] H.L. Wang, M. Miyauchi, T. Takata, J. Periodontal Res. 37 (2002) 340 .
[17] B.D. Boyan, T.W. Hummert, D.D. Dean, Z. Schwartz, Biomaterials 17 (1996) 137.

[18] K. Anselme, P. Linez, M. Bigerelle, D. Le Maguer, A. Le Maguer, P. Hardouin, H.F. Hildebrand, A. Iost, J.M. Leroy, Biomaterials 21 (2000) 1567.

[19] C.H. Thomas, C.D. McFarland, M.L. Jenkins, A. Rezania, J.G. Steele, K.E. Healy, J. Biomed. Mater. Res. 37 (1997) 81.

[20] J.M. Schakenraad, H.J. Busscher, C.R. Wildevuur, J. Arends, Cell Biophys. 13 (1988) 75.

[21] H. Zreiqat, P. Evans, C.R. Howlett, J. Biomed. Mater. Res. 44 (1999) 389.

[22] K. Anselme, M. Bigerelle, B. Noel, E. Dufresne, D. Judas, A. Iost, P. Hardouin, J. Biomed. Mater. Res. 49 (2000) 155.

[23] M.J. Dalby, L. Di Silvio, G.W. Davies, W. Bonfield, J. Mater. Sci., Mater. Med. 12 (2000) 805.

[24] R.L. Reis, S.C. Mendes, A.M. Cunha, M.J. Bevis, Polym. Int. 43 (1997) 347.

[25] P.B. Malafaya, C. Elvira, A. Gallardo, J. San Roman, R.L. Reis, J. Biomed. Sci., Polym. Ed. 12 (2001) 1227.

[26] I. Espigares, C. Elvira, J.F. Mano, B. Vázquez, J. San Roman, R.L. Reis, Biomaterials 23 (2002) 1883.

[27] M.E. Gomes, J.S. Godinho, D. Tchalamov, A.M. Cunha, R.L. Reis, Mater. Sci. Eng., C, Biomim. Mater., Sens. Syst. 20 (2002) 19.

[28] K. Webb, V. Hlady, P.A. Tresco, J. Biomed. Mater. Res. 49 (2000) 362.

[29] S.A. Redey, M. Nardin, D. Bernache-Assolant, C. Rey, P. Delannoy, L. Sedel, P.J. Marie, J. Biomed. Mater. Res. 50 (2000) 353.

[30] U. Mayr-Wohlfart, J. Fiedler, K.P. Gunther, W. Puhl, S. Kessler, J. Biomed. Mater. Res. 57 (2001) 132.

[31] T. Matsuura, R. Hosokawa, K. Okamoto, T. Kimoto, Y. Akagawa, Biomaterials 21 (2000) 1121.

[32] P.R. Kinneard, C.D. Gray, SPSS for Windows: Made Simple, Psychology Press, Hove, 1999.

[33] C.M. Alves, R.L. Reis, J.A. Hunt, J. Mater. Sci., Mater. Med. 14 (2003) 157.

[34] H. Zreiqat, C. McFarland, C.R. Howlett, J. Biomater. Sci., Polym. Ed. 10 (1999) 199.

[35] Y. Ikarashi, T. Tsuchiya, A. Nakamura, Biomaterials 21 (2000) 1259

[36] K.E. Healy, C.H. Thomas, A. Rezania, J.E. Kim, P.J. McKeown, B. Lom, P.E. Hockberger, Biomaterials 17 (1996) 195.

[37] C.J. Kirkpatrick, A. Dekker, Adv. Biomater. 10 (1992) 31.

[38] U. Meyer, D.H. Szulczewski, K. Moller, H. Heide, D.B. Jones, Cell Mater. 3 (1993) 129.

[39] V. Svorcik, V. Rybka, V. Hnatowicz, L. Bacakova, J. Mater. Sci. Lett. 14 (1995) 1723.

[40] B. Feng, J. Weng, B.C. Yang, S.X. Qu, X.D. Zhang, Biomaterials 24 (2003) 4663.

[41] J.G. Steele, G. Johnson, K.M. McLean, G.J. Beumer, H.J. Griesser, J. Biomed. Mater. Res. 50 (2000) 475.

[42] K. Cai, K. Yao, S. Lin, Z. Yang, X. Li, H. Xie, T. Qing, L. Gao, Biomaterials 23 (2002) 1153.

[43] I. Pashkuleva, A.P. Marques, F. Vaz, R.L. Reis, J. Mater. Sci., Mater. Med. (2004) 1-12.

[44] J.Y. Martin, Z. Schwartz, T.W. Hummert, D.M. Schraub, J. Simpson, J. Lankford Jr., D.D. Dean, D.L. Cochran, B.D. Boyan, J. Biomed. Mater. Res. 29 (1995) 389

[45] D. De Santis, C. Guerriero, P.F. Nocini, J. Mater. Sci., Mater. Med. 7 (1996) 21.

[46] M. Lampin, C. Warocquier, C. Legris, M. Degrange, M.F. SigotLuizard, J. Biomed. Mater. Res. 36 (1997) 99.

[47] H. Zreiqat, O.C. Standard, T. Gegenbach, J.G. Steele, C.R. Howlett, Cell Mater. 1-3 (1996) 45.

[48] A.P. Marques, I.B. Leonor, R.L. Reis, J. Hunt, In vitro evaluation of the effect of starch-based biodegradable polymers in human leukocytes, 28th Annual Meeting of The Society for Biomaterials, Society for Biomaterial, Tampa, Florida, USA, 2002, pp. 647. 
[49] T. Okano, N. Yamada, M. Okuhara, H. Sakai, Y. Sakurai, Biomaterials 16 (1995) 297.

[50] T.H. Young, C.H. Yao, J.S. Sun, C.P. Lai, L.W. Chen, Biomaterials 19 (1998) 717.

[51] U. Geissler, U. Hempel, C. Wolf, D. Scharnweber, H. Worch, K. Wenzel, J. Biomed. Mater. Res. 51 (2000) 752

[52] J.H. Wang, C.H. Yao, W.Y. Chuang, T.H. Young, J. Biomed. Mater. Res. 51 (2000) 761.

[53] K. Matsuzaka, X.F. Walboomers, M. Yoshinari, T. Inoue, J.A. Jansen, Biomaterials 24 (2003) 2711.

[54] M. Bigerelle, K. Anselme, B. Noel, I. Ruderman, P. Hardouin, A. Iost, Biomaterials 23 (2002) 1563.

[55] U. Jonsson, B. Ivarsson, I. Lundstrom, L. Berghem, J. Colloid Interface Sci. 90 (1982) 148.

[56] W.G. Pitt, D.F. Fabrizius-Homan, D.F. Mosher, S.L. Cooper, J. Colloid Interface Sci. 129 (1989) 231.

[57] C.D. McFarland, S. Mayer, C. Scotchford, B.A. Dalton, J.G. Steele, S. Downes, J. Biomed. Mater. Res. 44 (1999) 1.

[58] J.G. Steele, B.A. Dalton, G. Johnson, P.A. Underwood, J. Biomed. Mater. Res. 27 (1993) 927.

[59] C.R. Howlett, M.D.M. Evans, W.R. Walsh, G. Johnson, J.G. Steele, Biomaterials 15 (1994) 213

[60] A. El-Ghannam, P. Ducheyne, I.M. Shapiro, J. Orthop. Res. 17 (1999) 340 .
[61] P.A. Underwood, F.A. Bennett, J. Cell. Sci. 93 (Pt. 4) (1989) 641.

[62] J.S. Sun, H.C. Liu, W.H. Chang, J. Li, F.H. Lin, H.C. Tai, J. Biomed. Mater. Res. 39 (1998) 390.

[63] E.J. Evans, Biomaterials 12 (1991) 574

[64] R.W. Evans, H.S. Cheung, D.J. McCarty, Calcif. Tissue Int. 36 (1984) 645.

[65] H.S. Cheung, D.J. McCarty, Exp. Cell Res. 157 (1985) 63.

[66] T. Takahashi, N. Kurihara, K. Takahashi, M. Kumegawa, Arch. Oral Biol. 31 (1986) 703.

[67] M. Gregoire, I. Orly, J. Menanteau, J. Biomed. Mater. Res. 24 (1990) 165.

[68] S. Best, B. Sim, M. Kayser, S. Downes, J. Mater. Sci., Mater. Med. 8 (1997) 97.

[69] M.E. Gomes, R.L. Reis, A.M. Cunha, C.A. Blitterswijk, J.D. de Bruijn, Biomaterials 22 (2001) 1911.

[70] SC Mendes, R.L. Reis, Y.P. Bovell, A.M. Cunha, C.A. van Blitterswijk, J.D. de Bruijn, Biomaterials 22 (2001) 2057.

[71] A.P. Marques, R.L. Reis, J.A. Hunt, Biomaterials 23 (2002) 1471.

[72] S.C. Rizzi, D.J. Heath, A.G. Coombes, N. Bock, M. Textor, S. Downes, J. Biomed. Mater. Res. 55 (2001) 475.

[73] A. El-Ghannam, P. Ducheyne, I.M. Shapiro, J. Biomed. Mater. Res. 36 (1997) 167. 